\title{
Research on Accounting Practice Teaching System: Taking the Accounting Major of Qilu University of Technology as an Example
}

\author{
Xiang-ling Kong \\ Qilu University of Technology, Jinan, Shandong, China
}

\begin{abstract}
Social demands for accounting graduates show the characteristics of compound, skilled and practical and it puts forward a new subject for college training mode, namely in addition to theoretical knowledge, to improve the actual work ability of graduates is also very important. So in the process of teaching, the practice teaching link must be strengthened. By taking Qilu University of Technology as an example, this paper introduces the basic practices and successful experiences in accounting practice teaching, analyzes the existing problems in colleges accounting practice teaching system and proposes some specific improvement measures.
\end{abstract}

Key words-Accounting, Practice teaching system, Qilu University of Technology, Research

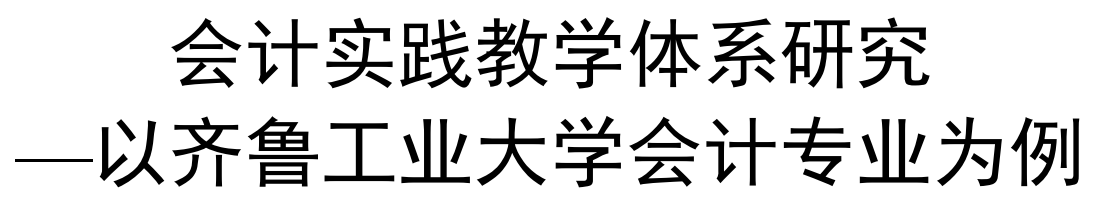

孔祥玲

齐鲁工业大学, 济南, 山东, 中国

摘 要 社会用人单位对会计专业毕业生的需求呈现出复合型、技能型、实用型的特点, 这种变化趋势对高校的人才培养模式提 出了新的课题, 即在传授理论知识的同时, 必须注重提高毕业生的实际工作能力, 因此, 在教学过程中, 必须强化实践教学环节。本 文以齐鲁工业大学会计专业为例, 介绍了该校在会计实践教学方面的基本做法和成功经验, 分析了目前高校会计实践教学体系存在的 问题，进而提出完善高校会计实践教学体系的具体措施。

关键词 会计, 实践教学体系, 齐鲁工业大学, 研究

随着中国市场经济的迅速发展，社会经济业务繁杂多 变，会计用人单位需要复合型、技能型、实用型的人才， 因此，培养既具备会计理论知识，又具备较强实践能力的 高端技能型人才将成为高校会计专业的未来目标。而培养 学生的实践能力, 关键在于强化实践教学环节。目前, 我 国各高校已经加大实践课比例, 但是尚未达到企业和社会 期望的成效。因此, 在原有会计实践教学的基础上, 改革 完善会计实践教学体系, 全方位强化实践教学环节, 加快 转换人才培养模式, 切实提高会计专业创新性应用型人才 的培养水平, 是高校会计专业实践教学的重中之重。本文 以齐鲁工业大学会计专业为例对高校会计专业实践教学体
系进行研究。

\section{1. 齐鲁工业大学会计专业实践教学概况}

齐鲁工业大学会计专业历史悠久, 是本校的重点专业, 分研究生、本科、专科三个教学层次, 研究生在校 20 余人, 本科在校近 1000 人, 专科在校 600 余人。

\section{1 教学计划安排}

从教学课程上, 本校结合不同层次的教学需求, 安排 了不同的教学计划, 设置相应的会计课程。如表 1: 
表 1 人才培养方案及授课计划

\begin{tabular}{|c|c|c|}
\hline 教学层次 & 主要会计理论教学课程 & 会计实践教学课程 \\
\hline & $\begin{array}{l}\text { 基础会计、中级财务会计、高级 } \\
\text { 财务会计、成本会计、管理会计、 } \\
\text { 税务会计、会计信息系统等 }\end{array}$ & $\begin{array}{l}\text { 会计模拟实验 (手 } \\
\text { 工账)、会计电算 } \\
\text { 化、校外实践 }\end{array}$ \\
\hline 专科 & $\begin{array}{l}\text { 基础会计、中级财务会计、成本 } \\
\text { 会计、管理会计、税务会计等 }\end{array}$ & $\begin{array}{l}\text { 会计模拟实验 (手 } \\
\text { 工账)、会计电算 } \\
\text { 化、校外实践 }\end{array}$ \\
\hline
\end{tabular}

1.2 会计模拟实验教学的实施

从表 1 可以看出, 会计实践教学的主要手段是会计模 拟实验, 它的实施主要依靠会计实验室和任课教师的指导。

\subsection{1 会计模拟实验的内容}

会计模拟实验主要以《会计模拟实验》教材为蓝本, 对教材中设立的模拟企业的经济业务进行模拟处理, 由于 目前现有的教材对税务会计和管理会计的内容涉及甚少, 因此, 会计模拟实验实质上主要是对基础会计、财务会计、 成本会计的内容进行模拟操作。主要内容见表 2:

表 2 会计模拟实验教学的内容

\begin{tabular}{|c|c|}
\hline 实验模块 & \multicolumn{1}{|c|}{ 实验操作的具体内容 } \\
\hline \multirow{2}{*}{ 基础会计 } & $\begin{array}{l}\text { 原始凭证的填制和审核;记账凭证的填制; } \\
\text { 账簿 (日记账、明细账、总账、备查账) 的登记; } \\
\text { 科目汇总表的编制; 会计报表的编制等。 }\end{array}$ \\
\hline 财务会计 & 经济业务的账务处理和会计报表的编制 \\
\hline 成本会计 & 品种法、分步法的成本计算 \\
\hline 会计电算化 & 利用会计软件进行账务处理 \\
\hline
\end{tabular}

\subsection{2 能力综合实训和评判标准}

通过对模拟企业经济业务的处理, 全面地提升学生对 业务知识系统性的理解和把握, 锻炼他们综合运用多门课 程知识解决实际问题的能力, 同时培养学生良好的职业道 德、职业判断能力和实际操作能力。能力综合实训评判见 图 1:

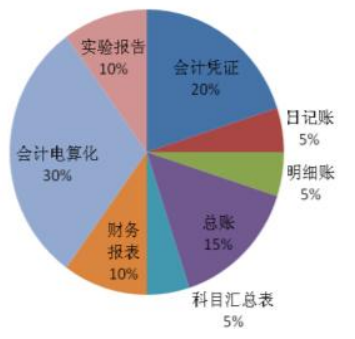

图 1 能力综合实训各部分评分比例
达标标准： 85 分以上, 为优秀; 70-85 分, 为良好; 60-70 分, 为及格; 60 分以下, 为不及格。

\section{2.会计实践教学的效果调查}

本校自会计实践教学实施以来, 通过多年的不断改革, 已形成较为完善的实践教学体系, 收到了良好的教学效果。 通过对学生和用人单位针对性的访问调查、电话调查、召 开座谈会、个人深度访问等形式, 对会计专业实践教学效 果有了总体的认识, 同时也了解到会计职业界对会计毕业 生的评价及其对会计教育的要求。

\section{1 激发了学生的学习兴趣}

会计理论教学是以教师讲授为主, 经济业务用文字描 述, 凭证以分录代替,账簿则采用“ $\mathrm{T}$ ”型账, 这种教学模式, 久 而久之, 使学生觉得枯燥无味, 失去了学习的兴趣。而会计模 拟实验教学是把学生放置在一个特定的环境中, 学生是主 体, 亲自完成凭证的填制和审核、账簿的登记、对账与结账、 报表的编制等一系列工作, 既加深学生对会计理论知识的 系统理解, 又激发了学生学习的兴趣。

本次随机抽查了本科 312 人, 专科 172 人, 对接受会 计实践教学之前后的兴趣度进行了对比, 见表 3、图 2、图 3:

表 3: 学生对会计专业的兴趣调查结果汇总表

\begin{tabular}{|c|c|c|c|c|c|c|c|c|c|c|c|}
\hline \multirow{2}{*}{\multicolumn{2}{|c|}{$\begin{array}{l}\text { 学生对会计 } \\
\text { 专业的兴趣 }\end{array}$}} & \multicolumn{5}{|c|}{ 接受会计实践教学之前 } & \multicolumn{5}{|c|}{ 接受会计实践教学之后 } \\
\hline & & 高 & $\begin{array}{l}\text { 较 } \\
\text { 高 }\end{array}$ & 一 & $\begin{array}{l}\text { 较 } \\
\text { 低 }\end{array}$ & 低 & 高 & \begin{tabular}{|l|} 
较 \\
高
\end{tabular} & 一 & $\begin{array}{l}\text { 较 } \\
\text { 低 }\end{array}$ & 低 \\
\hline 本 & 人数 & 25 & 48 & 167 & 66 & 6 & 135 & 108 & 50 & 17 & 2 \\
\hline 科 & 比重\% & 8 & 15 & 54 & 21 & 2 & 43 & 35 & 16 & 5 & 1 \\
\hline 专 & 人数 & 39 & 43 & 54 & 29 & 7 & 87 & 51 & 26 & 7 & 1 \\
\hline 科 & 比重\% & 23 & 25 & 31 & 17 & 4 & 51 & 30 & 15 & 4 & 1 \\
\hline
\end{tabular}

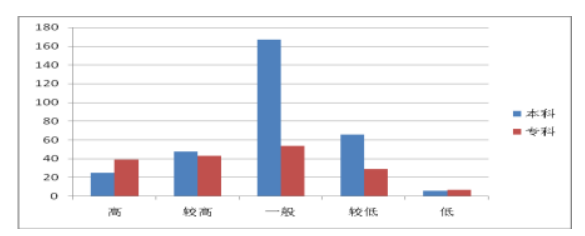

图 2 接受会计实践教学之前学生的兴趣度

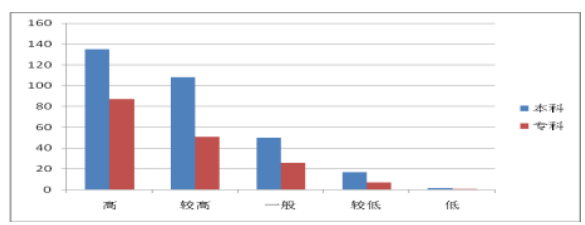

图 3 接受会计实践教学之后学生的兴趣度 


\section{2 加强了学生对所学会计专业知识的系统理解}

会计理论教学都是分章节讲解的, 一般按会计要素排 列章节, 各章节知识之间缺乏连接性, 学生掌握的知识是 孤立的, 会计模拟实验既是对学生动手能力的培养, 也是 对所学理论知识的复习和消化。通过实验教学, 使学生对 所学的理论知识进行系统性的理解, 达到融会贯通, 举一反 三。

\section{3 培养了学生的动手能力}

会计学是一门应用性学科, 操作性很强, 用人单位对 毕业生的要求越来越高, 希望毕业生能够尽快地适应工作 岗位。这就要求毕业生不仅要有扎实的会计理论知识, 还 要具备一定的实际操作能力。而这种动手能力的培养, 一 般有两个途径:一是校外实习, 二是校内的模拟实验。校外 实习由于种种原因, 往往不能取得较好的效果, 而校内模 拟实验则成为会计实践教学的重要形式, 基本能够达到培 养学生实际操作能力、融会贯通和灵活运用的目的。

\section{3. 会计专业实践教学存在的问题}

\section{1 实践教学目标缺乏高度性}

目前会计专业的实践教学目标主要定位在培养学生的 动手能力和操作能力, 还未上升到培养学生的职业道德、 敬业精神、综合能力与创新能力的层次上。

\section{2 理论教学与实践教学脱节}

会计课堂教学以会计要素为主线形成各章节的内容, 之间缺乏连贯性和系统性, 而且往往围绕校内考试和各种 社会从业资格证考试范围进行, 重核算轻管理, 而实践教 学和实际工作对如成本管理、存货管理、工资核算、报表 编制等内容更加重视, 导致理论教学与实践教学及实际工 作需求脱节较大。具体表现在: 学生专业知识掌握不扎实, 对知识含含糊糊, 模棱两可, 差错率较高, 灵活应变能力 差, 只会根据理论知识照搬照套, 不会灵活运用, 很难独 立开展实际工作。

\section{3 实践教学内容缺乏真实、全面和系统性}

模拟实验是实践教学的基本形式, 本校模拟给学生提 供的都是真实的凭证、账簿和报表, 但原始资料是一套虚 拟企业某年 12 月份的经济业务, 原始凭证是书本上印制的 格式, 限制了学生的感性认识。由于受各种条件的限制, 学生只能独立地完成一整套账务处理, 而无法按会计岗位 进行合理的分工, 无法体验会计的真实过程。另外, 实训
内容往往注重财务会计、成本会计等核算部分的专业技能 练习, 对管理会计、税收会计、财务管理、审计、内部控 制等内容涉及较少这种片面的训练难以培养学生的综合分 析能力和应用能力。

\section{4 校外实训基地在平时的教学中作用发挥不大}

大多数高校都有自己的校外实习基地, 比如与一些企 业、会计师事务所签订协议, 派送学生到企业实习等, 但 是企业的会计岗位人员充实, 且会计资料属于商业机密, 单位不愿意让学生顶岗实习, 学生在实习中很难真正从事 会计核算工作，实习效果难如人意。

\section{4.完善会计专业实践教学的措施}

\section{1 全方位提升会计实践教学目标}

目前市场对会计人才的要求是高标准的, 因此, 高校 也应全方位地提升会计实践教学的目标, 不仅要培养学生 的动手能力和实际操作能力, 还要要求学生严格遵守企业 会计准则、规章制度、职业道德和财经纪律等法律法规, 培养学生的职业道德、敬业精神、综合能力与创新能力, 向社会输送应用型、创新型和外向型的高级会计人才。

4.2 构建技能训练、课程案例、阶段模拟、综合实训、顶岗 实习五位一体的实践教学体系

(1)技能训练。高校会计实践教学应该涵盖会计活动的 全过程, 除了对会计经济业务的实践训练外, 还要重视基 本技能和基本功底的训练, 内容包括珠算、点钞、传票和 书写规范等基本技能。

(2)课堂案例。教师在授课过程中, 除了必需的理论知 识讲授外, 对每一教学模块的内容还要辅以相应的会计教 学案例, 通过案例分析, 让学生明确了解会计工作的细节, 认识到哪些能做, 那些不能做, 怎样做对, 怎样做不对, 这不但提高了学生的认知能力, 更重要的是培养了学生的 敬业精神和职业操守。

(3)阶段模拟。在完成一个模块或一门课程的教学之后, 要对学生进行阶段性的总结模拟。比如, 在基础会计学习 结束后, 利用一周时间进行本课程的阶段实训, 对不同账 务处理程序下的凭证填制与审核、账簿登记、错账更正、 对账与结账等内容进行全面的整合、实训, 把相对分散的 知识和技能利用阶段实训串联融通起来。

(4)综合实训。一般在毕业前一学期, 全部理论课程完 成以后, 利用 4-5 周的时间在校内模拟实验室进行综合实 训, 实训内容涵盖整个财务、会计工作流程, 按照会计工 作岗位分组进行。 
(5)顶岗实习。完成综合实训后, 学生对会计工作充满 兴趣和信心, 这时安排 6-8 周的时间去校外实习基地现场 实习, 通过现场观摩、接受实习基地工作人员指导、顶岗 实习等循环渐进的体验和历练, 完全能够顺利完成从学生 到社会会计人员的角色转换。

\section{3 拓宽会计实践教学的内容}

\subsection{1 将实践内容拓宽到多种类型的企业}

目前, 会计实训教材内容一般局限于制造型企业, 这 限制了学生的视野。实践教学内容应进一步拓宽到其他类 型的企业, 如商业、房地产、金融企业等, 使学生在毕业 后能适应多种类型企业的要求。

\subsection{2 将实践内容拓宽到本专业全部课程}

会计的基本职能是核算和监督, 而目前大部分高校的 实践内容仅限于核算, 监督管理的内容涉及甚少。因此, 会计实践内容除基础会计、财务会计、成本会计外, 还应 拓宽到管理会计、财务管理、成本管理、内部控制、资本 运作、税收筹划、纳税申报、电算化等各个环节, 将所学 全部课程纳入到实践教学的内容。

\subsection{3 将实践内容拓宽到会计流程的各个岗位}

根据财政部的会计岗位标准, 应设置出纳、往来、资 产、工资、收入、涉税、成本、会计报表等共 11 个会计岗 位, 学生应轮流模仿每个角色完成手工和电算化两部分实 训任务, 锻炼运用综合知识解决问题的能力, 培养学生良 好的职业判断能力和实践能力。

\subsection{4 注重会计电算化模拟和毕业论文的综合实训}

社会进步和科学技术的发展要求毕业生掌握较多的计 算机操作技巧, 会计电算化模拟不但提高了学生运用会计 电算化软件进行会计处理的技能, 而且能够使学生走上社 会之后, 较快地适应各种会计环境。

毕业论文是综合实践的重要环节, 在导师的指导下, 学生不仅掌握专业论文撰写的规范和技巧, 还是对学生会 计实践活动的检验和总结。学生通过最后的实习阶段, 深 入体会、认识和掌握会计流程的全过程, 才能对所学专业 有更系统和深刻的认识, 才能把握专业发展的最新前沿动 态, 才能写出高质量的毕业论文。

\section{4 提高专任教师实践能力, 聘请有经验的人员担任实践指} 导教师

\subsection{1 有计划有步骤地加强对教师理论水平和实践能力双提} 高的训练

高校应定期组织教师外出培训、参观学习; 鼓励教师
参加如会计师、注册会计师、资产评估师、注册税务师等 社会职业资格考试; 鼓励教师到企业现场实习; 鼓励教师 到企事业单位或会计事务所做兼职, 提高理论教师的实践 水平。

\subsection{2 聘请职业界具有实践经验的人士担任兼职教师或客座} 教授

将职业界具有实践经验的人士请进学校, 既可以指导 会计教学工作, 进行教师培训, 又可以让他们担任会计课 程教学, 把企业中的实际业务直接带到课堂中, 引导学生 们解决实际问题, 增强说服力和实践指导性, 以弥补在校 专任教师实践经验的不足。

\section{5 加强校外实习基地建设}

(1)选择重视学术研究的会计师事务所进行合作。会计 师事务所攻坚能力强, 所经营的业务齐全, 是高校最优的 “产学研”基地选择目标。教师可以以合作单位提供的资料 作为研究对象, 开发教学案例和教材; 学生可以全面地实 习理论课堂上的内容, 提高实践操作能力和解决实际问题 的能力。

(2)选择有合作意向的国有大型企业或集团进行合作。 国有大型企业或集团具有较强的人才吸纳力, 其母公司、 子公司、分公司等经济业务分门别类, 甚至跨行业经营, 是教师和学生最好的实习基地, 同时企业可以得到教师提 供的技术支持和咨询服务。

(3)选择部分在本行业具有代表性的中小型企业进行合 作。目前部分中小型企业缺乏高素质人才, 渴望得到理论 指导和技术支持, 学校可以根据合作企业的实际情况和具 体要求选择专业教师为企业提供服务, 如定期为企业财务 人员进行培训、帮助企业审计财务账目、帮助企业税务申 报等。这样, 一方面有利于理论教师提高自身的实践能力, 同时也让企业看到校企合作带来的良性成果, 从而提高企 业吸纳实习学生的积极性。

\section{参考文献(References)}

[1] Zhang Xuefen, Guo Pingping, "Dynamic Binding on Three Elements of Undergraduate Accounting Practice Teaching System," Finance and Accounting Monthly, 2011.

[2] Fang fang, Huang Yumei, "Thinking and Design of Accounting Practice Teaching Mode in College," New West, 2011.

[3] Chen Jianxin, "Comparison on College Practice Teaching Mode: Taking Germany, Canada, UK and Australia as examples," China-Asean Panorama, 2011.

[4] Sun Xiping, "Optimization of Undergraduate Accounting Practice Teaching Plan," Finance and Accounting Monthly, 2013. 